OPEN ACCESS

Edited by:

Yanjie Xie,

Nanjing Agricultural University, China

Reviewed by:

Angeles Aroca Aguilar, Instituto de Bioquímica Vegetal y

Fotosintesis (IBVF), Spain

Xin Liu,

Qingdao Agricultural University, China

Golam Jalal Ahammed,

Henan University of Science

and Technology, China

${ }^{*}$ Correspondence:

Jisheng $L i$

lijsh@nwafu.edu.cn

Specialty section:

This article was submitted to

Plant Physiology,

a section of the journal

Frontiers in Plant Science

Received: 31 May 2018 Accepted: 27 September 2018 Published: 17 October 2018

Citation:

Jia H, Chen S, Liu D, Liesche J,

Shi $C$, Wang J, Ren $M$, Wang $X$,

Yang J, Shi W and Li J (2018)

Ethylene-Induced Hydrogen Sulfide

Negatively Regulates Ethylene

Biosynthesis by Persulfidation of ACO

in Tomato Under Osmotic Stress.

Front. Plant Sci. 9:1517.

doi: 10.3389/fpls.2018.01517

\section{Ethylene-Induced Hydrogen Sulfide Negatively Regulates Ethylene Biosynthesis by Persulfidation of ACO in Tomato Under Osmotic Stress}

\author{
Honglei Jia ${ }^{1,2}$, Sisi Chen ${ }^{1}$, Dan Liu' ${ }^{1}$, Johannes Liesche ${ }^{1}$, Cong Shi ${ }^{1}$, Juan Wang ${ }^{3}$, \\ Meijuan Ren ${ }^{3}$, Xiaofeng Wang ${ }^{1}$, Jun Yang ${ }^{2}$, Wei Shi ${ }^{1}$ and Jisheng Li ${ }^{1 *}$ \\ 'Biomass Energy Center for Arid and Semi-Arid Lands, College of Life Sciences, Northwest A\&F University, Yangling, China, \\ ${ }^{2}$ School of Environmental Science and Engineering, Shaanxi University of Science and Technology, Xi'an, China, ${ }^{3}$ Northwest \\ A\&F University Life Science Research Core Services, Northwest A\&F University, Yangling, China
}

A number of recent studies identified hydrogen sulfide $\left(\mathrm{H}_{2} \mathrm{~S}\right)$ as an important signal in plant development and adaptation to environmental stress. $\mathrm{H}_{2} \mathrm{~S}$ has been proven to participate in ethylene-induced stomatal closure, but how the signaling pathways of $\mathrm{H}_{2} \mathrm{~S}$ and ethylene interact is still unclear. Here, we reveal how $\mathrm{H}_{2} \mathrm{~S}$ controls the feedbackregulation of ethylene biosynthesis in tomato (Solanum lycopersicum) under osmotic stress. We found that ethylene induced the production of $\mathrm{H}_{2} \mathrm{~S}$ in guard cells. The supply of hypotaurine ( $\mathrm{HT}$; a $\mathrm{H}_{2} \mathrm{~S}$ scavenger) or DL-pro-pargylglycine (PAG; a synthetic inhibitor of $\mathrm{H}_{2} \mathrm{~S}$ ) removed the effect of ethylene or osmotic stress on stomatal closure. This suggests that ethylene-induced $\mathrm{H}_{2} \mathrm{~S}$ is a downstream component of osmotic stress signaling, which is required for ethylene-induced stomatal closure under osmotic stress. We further found that $\mathrm{H}_{2} \mathrm{~S}$ inhibited ethylene synthesis through inhibiting the activity of 1-aminocyclopropane-1-carboxylic acid (ACC) oxidases (ACOs) by persulfidation. A modified biotin-switch method (MBST) showed that $\mathrm{H}_{2} \mathrm{~S}$ can induce persulfidation of LeACO1 and LeACO2 in a dose-dependent manner, and that persulfidation inhibits the activity of LeACO1 and LeACO2. We also found that LeACO1 is persulfidated at cysteine 60. These data suggested that ethylene-induced $\mathrm{H}_{2} \mathrm{~S}$ negatively regulates ethylene biosynthesis by persulfidation of LeACOs. In addition, $\mathrm{H}_{2} \mathrm{~S}$ was also found to inhibit the expression of $\angle E A C O$ genes. The results provide insight on the general mode of action of $\mathrm{H}_{2} \mathrm{~S}$ and contribute to a better understanding of a plant's response to osmotic stress.

Keywords: hydrogen sulfide, ethylene, persulfidation, feedback regulation, tomato, LeACOs, abiotic stress

\section{INTRODUCTION}

Hydrogen sulfide $\left(\mathrm{H}_{2} \mathrm{~S}\right)$ is recognized as the third endogenous gasotransmitter, following the discovery of nitric oxide and carbon monoxide (Tan et al., 2010). In plants, cysteine (Cys) metabolism is closely related to $\mathrm{H}_{2} \mathrm{~S}$ generation. Cys desulfhydrases (CDes) contribute to $\mathrm{H}_{2} \mathrm{~S}$ generation (Papenbrock et al., 2007). L-Cys desulfhydrase (LCD) and D-Cys desulfhydrase 
(D-CDES) degrade Cys to $\mathrm{H}_{2} \mathrm{~S}$, pyruvate, and ammonia and are responsible for the release of $\mathrm{H}_{2} \mathrm{~S}$ into the cell (Kopriva, 2006). $\mathrm{H}_{2} \mathrm{~S}$ signaling has been implicated in the regulation of photosynthesis, immunity, cell senescence, root growth, and stomatal closure (Wang et al., 2002; Xie et al., 2014; Jia et al., 2015). $\mathrm{H}_{2} \mathrm{~S}$ has been similarly recognized as a major signaling compound, involved in stress responses to osmotic stress, high salinity, drought, heavy metals, and oxidative stress (Christou et al., 2013; Li et al., 2014; Jia et al., 2016; Fang et al., 2016; Guo et al., 2017). Interestingly, $\mathrm{H}_{2} \mathrm{~S}$ seems to generally act via the modulation of hormone action, namely of ethylene, auxin, and abscisic acid (Hou et al., 2013; Scuffi et al., 2014; Jia et al., 2015). Not known, so far, is the molecular mechanism of how $\mathrm{H}_{2} \mathrm{~S}$ can affect hormone action.

Here, the mode of action of $\mathrm{H}_{2} \mathrm{~S}$ on ethylene signaling is investigated in tomato. Ethylene plays critical roles in fruit maturation, plant growth, and adaptation to environmental challenges (Lacey and Binder, 2014). Environmental stimuli, such as drought and mechanical injury, increase ethylene concentration in plant cells through increased ethylene biosynthesis (Groen and Whiteman, 2014). The biosynthesis of ethylene is mediated by 1-aminocyclopropane-1-carboxylic acid (ACC) synthases (ACSs) and ACC oxidases (ACOs). ACOs have been identified as the enzymes catalyzing the rate-limiting of ethylene biosynthesis (Bleecker and Kende, 2000). ACOs are encoded by a multi-gene family in plants. It is reported that Arabidopsis thaliana has five AtACO genes, and that Solanum lycopersicum has six LeACO genes (Kende, 1993). Expression analysis revealed that $A C O$ s show a high tissue specificity, with LeACO1 and LeACO2 expressed in guard cells (Spanu et al., 1991). Many reports show that the silencing of ACO genes or the inhibition ACO activity reduces ethylene content in plant cells (Chao et al., 2013; Satoh and Kosugi, 2017).

The biosynthesis of ethylene is regulated by a feedback mechanism and by other signaling molecules. For example, auxin was shown to induce ethylene synthesis via the transcription of ACOs in Oryza sativa (Argueso et al., 2007) and nitric oxide was shown to decrease ethylene content through inhibiting ethylene synthesis enzyme activity (Zhu et al., 2006). Recently, $\mathrm{H}_{2} \mathrm{~S}$ has been implicated in the regulation of ethylene action (Liu et al., 2011). It was reported that $\mathrm{H}_{2} \mathrm{~S}$ weakens the effect of ethylene on banana fruit ripening (Ge et al., 2017) and inhibits ethylene-induced cell senescence in kiwifruit (Gao et al., 2013). However, the mechanism of $\mathrm{H}_{2} \mathrm{~S}$ regulating ethylene biosynthesis is unknown.

The working hypothesis is that it acts by persulfidation, which is the post-translational modification of Cys residues to form a persulfide group (cysteine - $\mathrm{SH}$ groups are converted to - $\mathrm{SSH}$ ). Recent evidence indicates that persulfidation by endogenous $\mathrm{H}_{2} \mathrm{~S}$ regulates the function of certain proteins, such as ascorbate peroxidase1 and glyceraldehyde 3-phosphate dehydrogenase (Aroca et al., 2015, 2017b). In addition, persulfidation was demonstrated in vivo in Arabidopsis, and that AtACO1 could be among the many proteins that can be modified in this way (Aroca et al., 2017a). Therefore, we tested here if tomato ACOs are subject to $\mathrm{H}_{2} \mathrm{~S}$-induced persulfidation and if this is the mechanism by which $\mathrm{H}_{2} \mathrm{~S}$ modulates ethylene signaling in response to osmotic stress. Experiments were carried out on tomato because its sensitivity to osmotic stress has been recognized as a major challenge to increase the production efficiency of this important crop.

\section{MATERIALS AND METHODS}

\section{Plant Material and Chemical Treatments}

Tomato (S. lycopersicum) seeds (Liger) were purchased from the Tomato Research and Development Center of Xinjiang Shihezi Vegetable Research Institute. The seeds were sterilized with 3\% sodium hypochlorite for $15 \mathrm{~min}$, then washed with $\mathrm{ddH}_{2} \mathrm{O}$ for three times. The seeds were sown in a tray with vermiculite and cultivated in a climate chamber $[16 \mathrm{~h} / 8 \mathrm{~h}$, light/dark photoperiod, $60 \%$ relative humidity, temperature of $26^{\circ} \mathrm{C}$ (day) $/ 20^{\circ} \mathrm{C}$ (night)]. After the second leaf emerged, plants were moved to hydroponics cultures with $1 / 4$ Hoagland's nutrient solution $(\mathrm{pH}=6.5)$. After one-week adaptation, uniform individuals were selected and transplanted in the hydroponic pots with $1 / 2$ Hoagland's nutrient solution. After another week, the seedings were used for different treatments and analyses.

Experiment 1: Two-week-old tomato seedlings were supplied with between 0 and 25\% PEG6000 (PEG), $200 \mu \mathrm{M}$ NaHS and $1.0 \mathrm{~g} / \mathrm{L}$ ethephon for 3 days, and then the phenotype was observed. Two-week-old tomato seedlings were supplied with between 0 and 25\% PEG, $200 \mu \mathrm{M}$ NaHS and $1.0 \mathrm{~g} / \mathrm{L}$ ethephon for $6 \mathrm{~h}$, and then the stomatal aperture and relative water content (RWC) was measured.

Experiment 2: Two-week-old tomato seedlings were supplied with 25\% PEG, $200 \mu \mathrm{M}$ NaHS, $200 \mu \mathrm{M} \mathrm{H}_{2} \mathrm{~S}$ scavenger hypotaurine (HT; Shanghai Aladdin Biochemical Technologies), $2 \mu \mathrm{M}$ the $\mathrm{H}_{2} \mathrm{~S}$ inhibitor DL-propargylglycine (PAG; Shanghai Aladdin Biochemical Technologies), $1.0 \mathrm{~g} / \mathrm{L}$ Ethephon and $200 \mu \mathrm{M}$ the ethylene biosynthesis inhibitor aminoethoxyvinylglycine (AVG; Shanghai Aladdin Biochemical Technologies) for $6 \mathrm{~h}$, and then endogenous endogenous $\mathrm{H}_{2} \mathrm{~S}$ content was measured.

Experiment 3: Two-week-old tomato seedlings were supplied with $25 \%$ PEG and $200 \mu \mathrm{M}$ NaHS for 6-72 h, and then endogenous ethylene content and ACO activity was measured.

Experiment 4: Two-week-old tomato seedlings were supplied with 25\% PEG, $200 \mu \mathrm{M}$ NaHS and $1.0 \mathrm{~g} / \mathrm{L}$ Ethephon for $3 \mathrm{~h}$ or $24 \mathrm{~h}$, and then relative expression of LeACO1 and LeACO2 was measured.

\section{Relative Water Content Assay}

The sample was dried at $80^{\circ} \mathrm{C}$ for $48 \mathrm{~h}$. $\mathrm{RWC}=[(\mathrm{FW}-\mathrm{DW}) / \mathrm{FW}] \times 100 \%$.

\section{Stomatal Aperture Measurements}

Stomatal aperture was performed as described by Hou et al. (2013). The epidermis was stripped from tomato seedlings and immediately incubated in opening buffer $\left(0.1 \mathrm{mM} \mathrm{CaCl}_{2}\right.$, $50 \mathrm{mM} \mathrm{KCl}$ and $10 \mathrm{mM} \mathrm{MES}, \mathrm{pH}=6.1$ ) under light conditions $\left(200 \mu \mathrm{M} / \mathrm{m}^{2} / \mathrm{s}\right)$ for $3 \mathrm{~h}$. The epidermal peels with pre-opened stomatal were subsequently maintained in the same opening 
buffer and exposed to different treatments. After $90 \mathrm{~min}$, stomata were photographed using a light microscope. The stomatal aperture width was measured using ImageJ analysis software.

\section{Ethylene Content Assay}

Ethylene content quantification was performed as described by Li et al. (2014). Two-week-old tomato seedlings were supplied with $25 \%$ PEG and $200 \mu \mathrm{M}$ NaHS for $0-72 \mathrm{~h}$, every treatment contains six samples $(0,6,12,24,36$, and $72 \mathrm{~h})$. Each sample (2 g) was placed in 10-ml gas tight glass vessels and incubated at room temperature for $10 \mathrm{~h}$. After incubated for $10 \mathrm{~h}$ in the glass vessels, the sample of gas was used for the measurement of ethylene. One milliliter sample of gas was removed and analyzed with a flame ionizing gas chromatograph (model 3700, Varian Medical Systems, Palo Alto, CA, United States) equipped with Porapak Q column (80-100 mesh, $1 \mathrm{~m} \times 3.2 \mathrm{~mm})$. Oven, injector, and detector temperatures were 50,150 , and $200^{\circ} \mathrm{C}$, respectively.

\section{ACO Activity Assay}

1-aminocyclopropane-1-carboxylic acid (ACC) oxidases activity was determined using protein extracts obtained from tomato seedling leaves and the purified recombinant LeACO1 and LeACO2 proteins. Protein extraction buffer was $50 \mathrm{mM}$ Tris $\mathrm{pH}=7.4$. The activity of ACO was determined according to Madhaiyan et al. (2007). Recombinant proteins were pretreated with $200 \mu \mathrm{m}$ NaHS and $10 \mathrm{mM}$ DTT at $4^{\circ} \mathrm{C}$ for $20 \mathrm{~min}$, and then enzyme activity was analyzed. The enzyme activity was assayed at $30^{\circ} \mathrm{C}$ for $15 \mathrm{~min} .1 .5 \mathrm{~mL}$ of protein supernatant was incubated with $50 \mu \mathrm{M}$ FeSO4, $1 \mathrm{mM}$ ACC, and 5\% (v/v) $\mathrm{CO}_{2}$, and then the quantity of released ethylene was determined. The protein concentrations were estimated by Coomassie brilliant blue staining and using bovine serum albumin as a reference protein.

\section{$\mathrm{H}_{2}$ S Content Assay in Guard Cells and Whole Leaves}

The specific $\mathrm{H}_{2} \mathrm{~S}$ fluorescent probe 7-azido-4-methylcoumarin (AzMC; Sigma-Aldrich) was used for the analysis of $\mathrm{H}_{2} \mathrm{~S}$ content in guard cells. After treatments, leaves were incubated in $20 \mathrm{mM}$ HEPES NaOH buffer ( $\mathrm{pH} 7.5$ ) containing $20 \mu \mathrm{M}$ of the probe for $30 \mathrm{~min}$ in darkness $\left(25^{\circ} \mathrm{C}\right)$. Afterward, the leaves were washed three times (15 min each time) with fresh HEPES buffer, and guard cells were observed under a spinning-disc confocal microscope (Andor, United Kingdom, Revolution-WD). Z-stack were recorded to obtain information from the entire guard cell volume. ImageJ was used for the analysis of fluorescence intensity.

The content of endogenous $\mathrm{H}_{2} \mathrm{~S}$ was measured according to Chen et al. (2016). The leaves were ground and extracted in $10 \mathrm{~mL}$ of phosphate buffered saline ( $\mathrm{pH} 6.8,50 \mathrm{mM}$ ) containing $0.1 \mathrm{mM}$ EDTA and $0.2 \mathrm{mM}$ ascorbic acid. The homogenate was mixed in a test tube containing $100 \mathrm{mM}$ phosphate buffered saline $(\mathrm{pH}$ 7.4), $10 \mathrm{mM}$ L-cysteine and $2 \mathrm{mM}$ phosphopyridoxal at room temperature, and the released $\mathrm{H}_{2} \mathrm{~S}$ was absorbed in a zinc acetate trap. The trap consisted of a small glass tube containing $3 \mathrm{~mL}$ of $0.5 \%$ zinc acetate that was fixed to the bottom of the reaction bottle. After a $30 \mathrm{~min}$ reaction, $0.3 \mathrm{~mL}$ of $20 \mathrm{mM}$ dimethylp-phenylenediamine was dissolved in $7.2 \mathrm{mM} \mathrm{HCl}$ and was added to the trap. This was followed by injection of $0.3 \mathrm{~mL}$ of $30 \mathrm{mM}$ ferric ammonium sulfate in $1.2 \mathrm{~mL} \mathrm{HCl}$. After incubation for $15 \mathrm{~min}$ at room temperature, the amount of $\mathrm{H}_{2} \mathrm{~S}$ in the zinc acetate trap was determined colorimetrically at $667 \mathrm{~nm}$. A calibration curve was made according to the above method and $\mathrm{H}_{2} \mathrm{~S}$ content in seedlings was expressed as nmol $\mathrm{g}^{-1} \mathrm{DW}$.

\section{Recombinant Protein Expression and Site-Directed Mutagenesis}

For in vitro protein expression, the coding regions of LeACO1 (GI: 902763266) and LeACO2 (GI: 1049480165) were amplified and inserted in-frame into the plasmid pET30a. The recombinant his-tagged proteins were purified from Escherichia coli BL21 cells using Amylose Resin (New England Biolabs) following the manufacturer's manual. Site-directed mutagenesis was carried out using the Quickchange II Site-Directed Mutagenesis Kit (Stratagene) following the manufacturer's manual. The primers used in this study are listed in Supplementary Table S1.

\section{Immunochemical Detection of Persulfidated LeACOs}

Persulfidated proteins were detected using a modified biotinswitch method (MBST, Mustafa et al., 2009). The purified recombinant LeACO1 and LeACO2 proteins were treated with 50 to $400 \mu \mathrm{M}$ NaHS to increase the concentration of persulfidated protein or with $10 \mathrm{mM}$ DTT to reduce all of the disulfide bonds; both treatments were carried out at $4^{\circ} \mathrm{C}$ for $20 \mathrm{~min}$. NaHS was removed using Micro BioSpinP6columns (BioRad). The proteins were blocked with $20 \mathrm{mM}$ methyl methanethiosulfonate (MMTS), and the persulfidated cysteines were labeled by $4 \mathrm{mM}$ biotin in the presence of N- [6-(biotinamido) hexyl]-39( $2^{\prime}$-pyridyldithio)-propionamide (biotin-HPDP). Persulfidated proteins were detected by immunoblot using an anti-biotin antibody (Sino Biological). The total amount of LeACO1 and LeACO2 proteins was determined using an anti-his antibody (Sino Biological). Persulfidated proteins were detected by antibiotin antibody (YEASEN). Antibodies working concentration: anti-his antibody is $10 \mathrm{mU} / \mathrm{ml}$, anti-biotin antibody is $0.5 \mu \mathrm{g} / \mathrm{ul}$. Gray analysis of Image J software ${ }^{1}$ was used for quantification persulfidated levels.

\section{Identification of Persulfidated Cys Residues}

Purified recombinant protein was separated using non-reducing SDS-PAGE on $12 \%(\mathrm{w} / \mathrm{v})$ polyacrylamide gels, and the bands corresponding to LeACO1 was excised manually from Coomassie-stained gels and then deposited in 96-well plates. Samples were alkylated by $50 \mathrm{mM}$ iodoacetamide (SigmaAldrich) for $40 \mathrm{~min}$ in darkness. Disulfide bonds were restored by treatment with $10 \mathrm{mM} \mathrm{DTT}$ at $37^{\circ} \mathrm{C}$ for $3 \mathrm{~h}$. Samples were digested by Trypsin (Promega) at a mass ratio of 1:50 in $37^{\circ} \mathrm{C}$ for $16 \mathrm{~h}$. Digested peptides were dissolved in sample

\footnotetext{
${ }^{1}$ rsb.info.nih.gov/ij/
} 
solution ( $0.1 \%$ formic acid and $2 \%$ acetonitrile), and centrifuged at $13200 \mathrm{rpm}$ at $4^{\circ} \mathrm{C}$ for $10 \mathrm{~min}$. The supernatant was analyzed by mass spectrometry (Thermo Scientific Q Exactive) using a chromatographic column of $300 \mu \mathrm{m}$ i.d. $\times 5 \mathrm{~mm}$ packed with Acclaim PepMap RPLC C18, $5 \mu \mathrm{m}, 100 \AA$ and a column of $75 \mu \mathrm{m}$ i.d. $\times 150 \mathrm{~mm}$, packed with Acclaim PepMap RPLC C18, $3 \mu \mathrm{m}, 100 \AA$ A. Mobile phase A: 0.1\% methanoic acid and 2\% ACN. Mobile phase B: $0.1 \%$ methanoic acid and $80 \%$ ACN. Flow

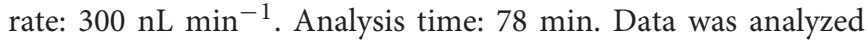
by Maxquant software referencing the Uniprot database. Peptide mass tolerance was set to $10 \mathrm{ppm}$. 0.6 Da fragment masses and two miss cleavages were adopted in this experiment. Peptides score $\geq 20$ were considered correctly identified.

\section{RNA Isolation and qRT-PCR}

Leaves of tomato seedling were harvested to extract total RNA for real-time PCR. Total RNA was extracted using RNAprep pure plant kit (Takara bio, Beijing) and treated with RNase free DNase (Takara bio, Beijing). The total RNA was reverse-transcribed into first-strand cDNA using PrimeScriptTM Reverse Transcriptase and Oligo (dT)15 primer following the manufacturer's instructions. The samples were amplified using SYBR Green I (SYBR ${ }^{\circledR}$ Premix Ex TaqTM Kit, Takara bio, Beijing), Real-time system used the BIO-RAD CFXF96. The housekeeping gene Ubi3 was used as an internal control. The PCR amplifications for each gene were performed in triplicate. The results were analyzed by Rotor-Gene Real-Time Analysis Software 6.1 (Build 81). The primers used in this study are listed in Supplementary Table S1.

\section{Statistical Analysis}

Each experiment was repeated at least three times with three replications per experiment. Values were expressed as means \pm SE. For all experiments, the overall data were statistically analyzed in SPSS version 17.0 (SPSS). Duncan's multiple range tests were used. The statistical analysis of two groups was performed using Student's $t$-test. In all cases, the confidence coefficient was set at 0.05 .

\section{RESULTS}

\section{$\mathrm{H}_{2} \mathrm{~S}$ and Ethylene Induce Stomatal Closure and Water Retention Under Osmotic Stress}

Exposure of tomato seedlings to 15 or $25 \%$ PEG resulted in softening of shoots and severe wilting of leaves (Figure 1A). Treatment with the $\mathrm{H}_{2} \mathrm{~S}$ precursor NaHS or the ethylene donor ethephon partly prevented this PEG-response (Figure 1A). Plants treated with NaHS or ethephon showed a higher rate of stomatal closure compared to control plants (Figure 1B). While PEG treatment caused the relative water content of leaves to decrease in control plants, plants treated with NaHS or ethephon did not show any reduction in response to $15 \%$ PEG, and relative water content decreased slightly in response to $25 \%$ PEG (Figure 1C). This data suggested that $\mathrm{H}_{2} \mathrm{~S}$ and ethylene

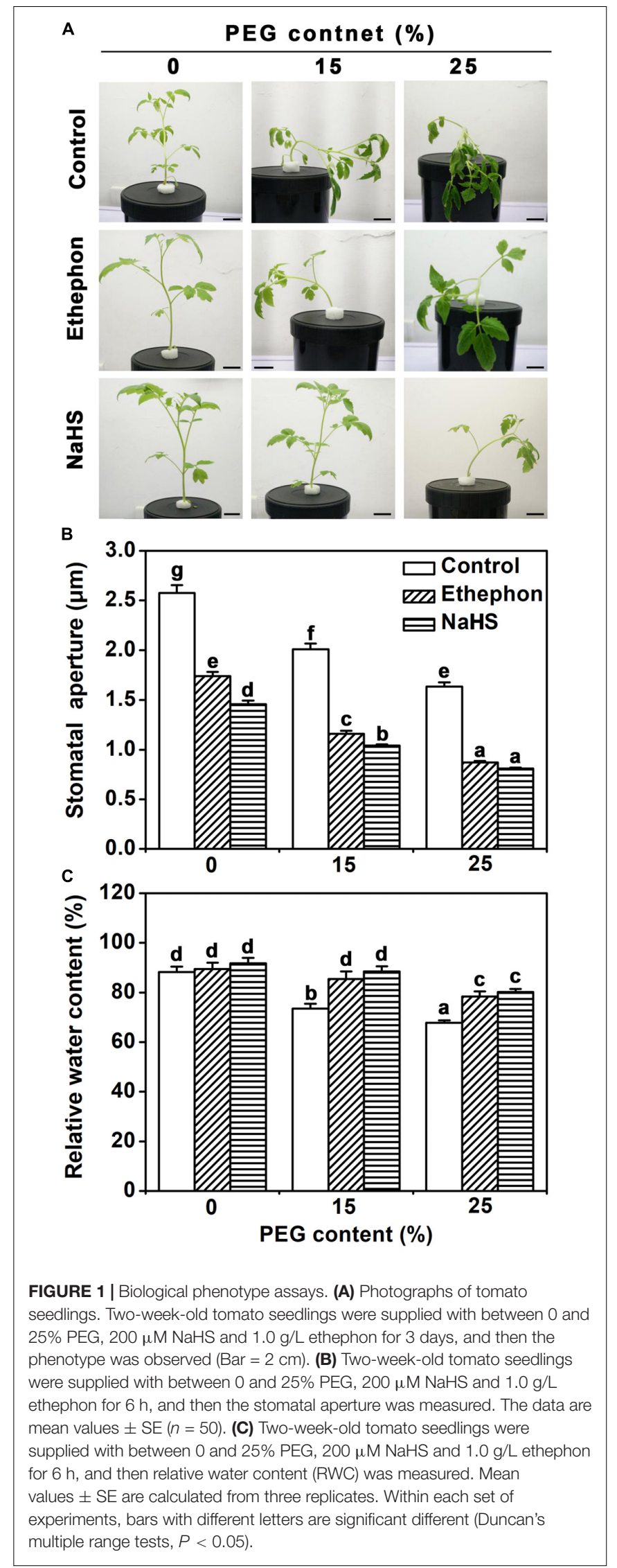




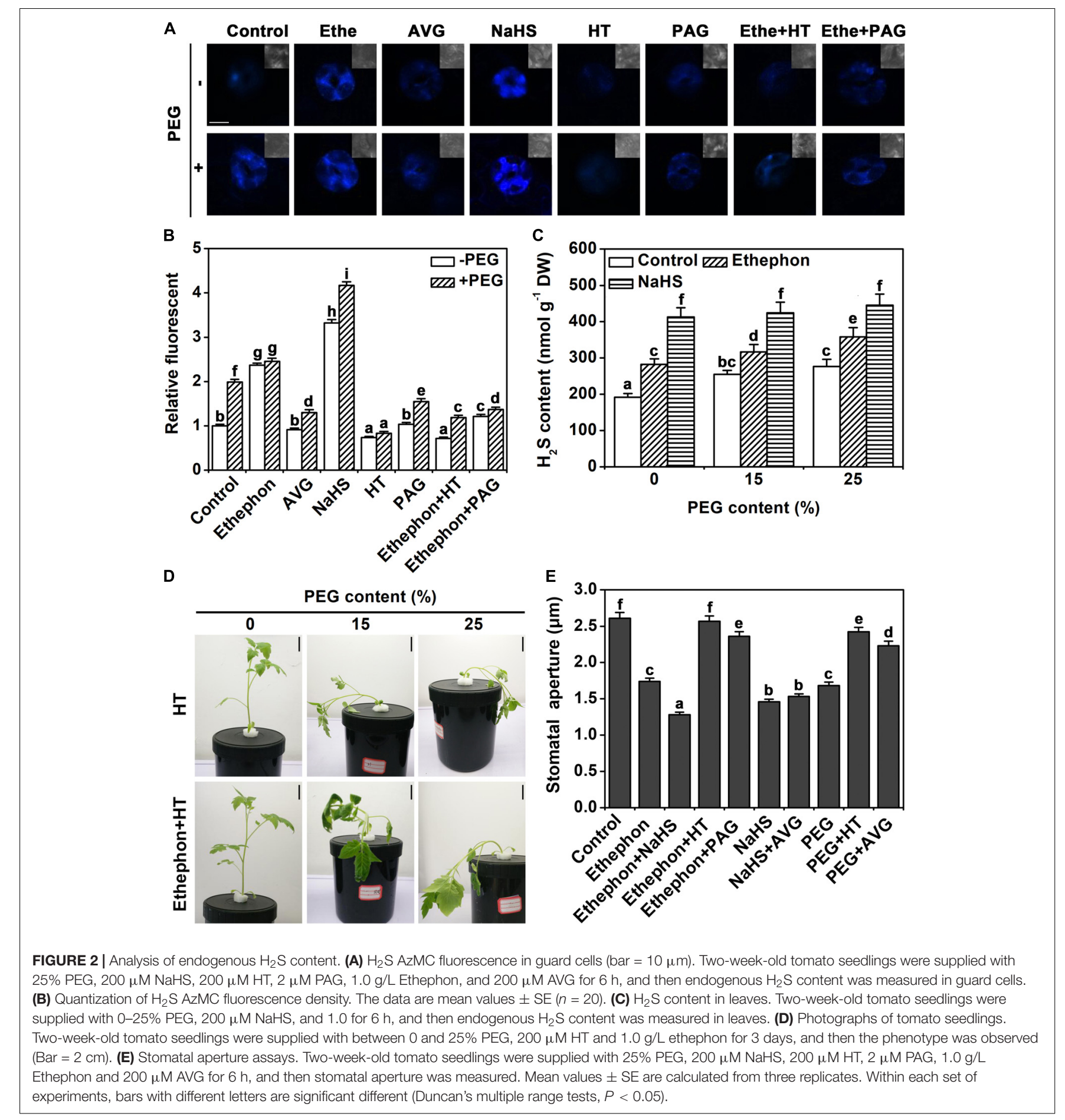

influence the osmotic stress response via regulation of stomata closure.

\section{Ethylene Induces Accumulation of $\mathbf{H}_{2} \mathbf{S}$}

In a next step, we tested how the $\mathrm{H}_{2} \mathrm{~S}$ content in guard cells changes in response to the different treatments using the fluorescent probe 7-azido-4-methylcoumarin (AzMC). Ethephon and osmotic stress both increased the endogenous $\mathrm{H}_{2} \mathrm{~S}$ content
(Figures 2A,B). Aminoethoxyvinylglycine (AVG, the ethylene biosynthesis inhibitor) did not alter the $\mathrm{H}_{2} \mathrm{~S}$ content in control condition, but it inhibited the accumulation of $\mathrm{H}_{2} \mathrm{~S}$ under osmotic stress conditions (Figures 2A,B). Treatment with hypotaurine ( $\mathrm{HT}$, a $\mathrm{H}_{2} \mathrm{~S}$ scavenger), or DL-pro-pargylglycine (PAG, a synthetic inhibitor of $\mathrm{H}_{2} \mathrm{~S}$ ) prevented the accumulation of $\mathrm{H}_{2} \mathrm{~S}$ under osmotic stress. HT or PAG treatment also inhibited ethylene-induced $\mathrm{H}_{2} \mathrm{~S}$ accumulation (Figures 2A,B). In addition, 
treatment with NaHS significantly enhanced $\mathrm{H}_{2} \mathrm{~S}$ content in control condition or osmotic stress (Figures 2A,B). $\mathrm{H}_{2} \mathrm{~S}$ contents also were analyzed in the whole leaf in the presence of PEG at various concentrations. Data showed that the supply of 15 and 25\% PEG induced $\mathrm{H}_{2} \mathrm{~S}$ accumulation (Figure 2C). Ethephon also increased $\mathrm{H}_{2} \mathrm{~S}$ content in both control and stress conditions in whole leaves (Figure 2C).

\section{$\mathrm{H}_{2} \mathrm{~S}$ Is Involved in Ethylene-Induced Stomatal Closure}

The wilting of the seedling was aggravated by HT under osmotic stress (Figure 2D). In addition, treatment with HT removed the effect of ethylene on osmotic stress (Figure 2D). To further investigate the relationship between $\mathrm{H}_{2} \mathrm{~S}$ and ethylene on stomatal closure, a pharmacological experiment was performed. As indicated above, $\mathrm{H}_{2} \mathrm{~S}$, ethylene, and osmotic stress signals induced stomatal closure. The supply of HT or PAG countered the effect of ethylene or osmotic stress on stomatal closure (Figure 2E). However, the supply of AVG did not change the effect of $\mathrm{H}_{2} \mathrm{~S}$ signal (Figure 2E). This result indicates that $\mathrm{H}_{2} \mathrm{~S}$ may be an essential part of the signaling network of osmotic stress-induced stomatal closure.

\section{$\mathrm{H}_{2} \mathrm{~S}$ Inhibits Ethylene Content in Leaves}

In addition to $\mathrm{H}_{2} \mathrm{~S}$ content, also concentrations of ethylene were measured. As shown in Figure 3A, under osmotic stress, ethylene content increased after $6 \mathrm{~h}$ and reached the maximum after $24 \mathrm{~h}$, and then decreased after $48 \mathrm{~h}$. NaHS treatment significantly decreased ethylene content under control condition, and it also weakened the increase of osmotic stress-induced ethylene content (Figure 3A). In line with the change of ethylene content, ACC oxidase activity was increased by osmotic stress at the $6 \mathrm{~h}$ and $24 \mathrm{~h}$ time points (Figure 3B). NaHS treatment inhibited the activity of ACC oxidase under control and osmotic stress conditions (Figure 3B). These results suggest that $\mathrm{H}_{2} \mathrm{~S}$ may inhibit ethylene biosynthesis through negatively regulating ACC oxidase activity.

\section{$\mathrm{H}_{2} \mathrm{~S}$-Induced Persulfidation of LeACO}

To determine how the activity of ACC oxidases is regulated by $\mathrm{H}_{2} \mathrm{~S}$, persulfidation assays were performed. The two ACC oxidases of tomato leaves, LeACO1 and LeACO2, were heterologously expressed and purified. Results indicated that NaHS induced persulfidation of LeACO1 and LeACO2 in a dose-dependent manner and that persulfidation was abolished by the application of DTT (Figures 4A-D). This shows that both proteins can be persulfidated by $\mathrm{H}_{2} \mathrm{~S}$ in vitro.

To confirm the effect of persulfidation on ACC oxidase activity, the purified recombinant proteins were pretreated with $\mathrm{NaHS}$ or NaHS + DTT. NaHS pretreatment inhibited LeACO1 and LeACO2 activities in a dose-dependent manner. The addition of DTT canceled out the effect of NaHS (Figures 4E,F). These data suggested that $\mathrm{H}_{2} \mathrm{~S}$ negatively regulates the activity of ACC oxidase activity by persulfidation in vitro.

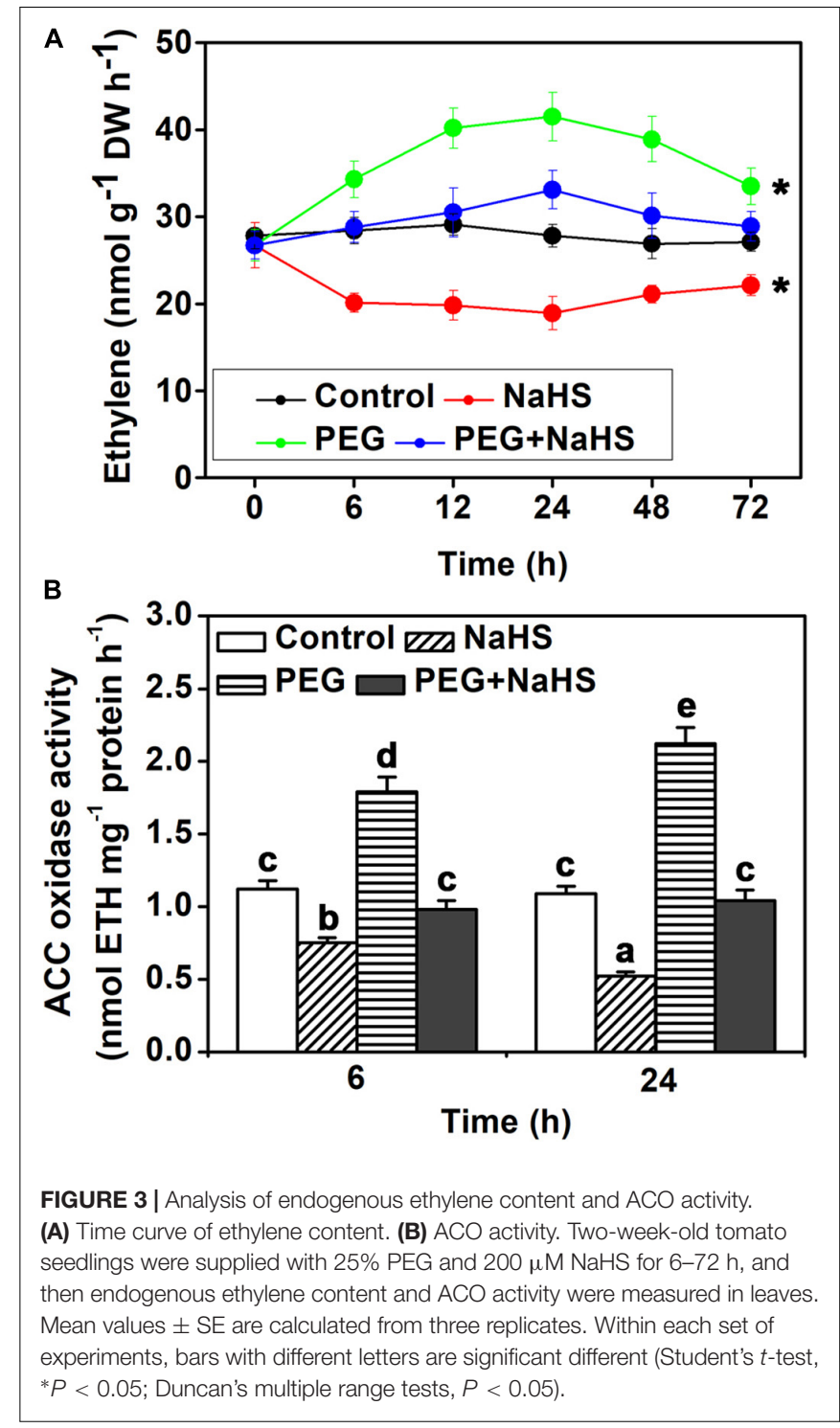

\section{The Location of Persulfidation Sites in LeAC01}

Four cysteine residues in LeACO1 and LeACO2 are putative target sites of persulfidation. We carried out liquid chromatography (LC)-tandem mass spectrometry (MS/MS) analysis on the recombinant LeACO1 protein. The mass of Cys60 increased, which suggested that this residue had gained a sulfhydryl modification (Figure 5A). To determine whether the Cys60 residue is required for NaHS-mediated persulfidation, we mutated each cysteine (C) to serine (S) separately in LeACO1 and tested the effect of NaHS on the modified proteins. Of the four mutations, only the Cys60Ser (C60S) mutation eliminated persulfidation by NaHS (Figure 5B). To confirm that LeACO1 is persulfidated at Cys60 in the presence of the $\mathrm{H}_{2} \mathrm{~S}$ donor, the recombinant LeACO1 ${ }^{\mathrm{C} 60 \mathrm{~S}}$ mutation protein was purified. The activity of LeACO $1^{\mathrm{C} 60 \mathrm{~S}}$ was similar with LeACO $1^{\mathrm{WT}}$ in vitro. However, compared with 

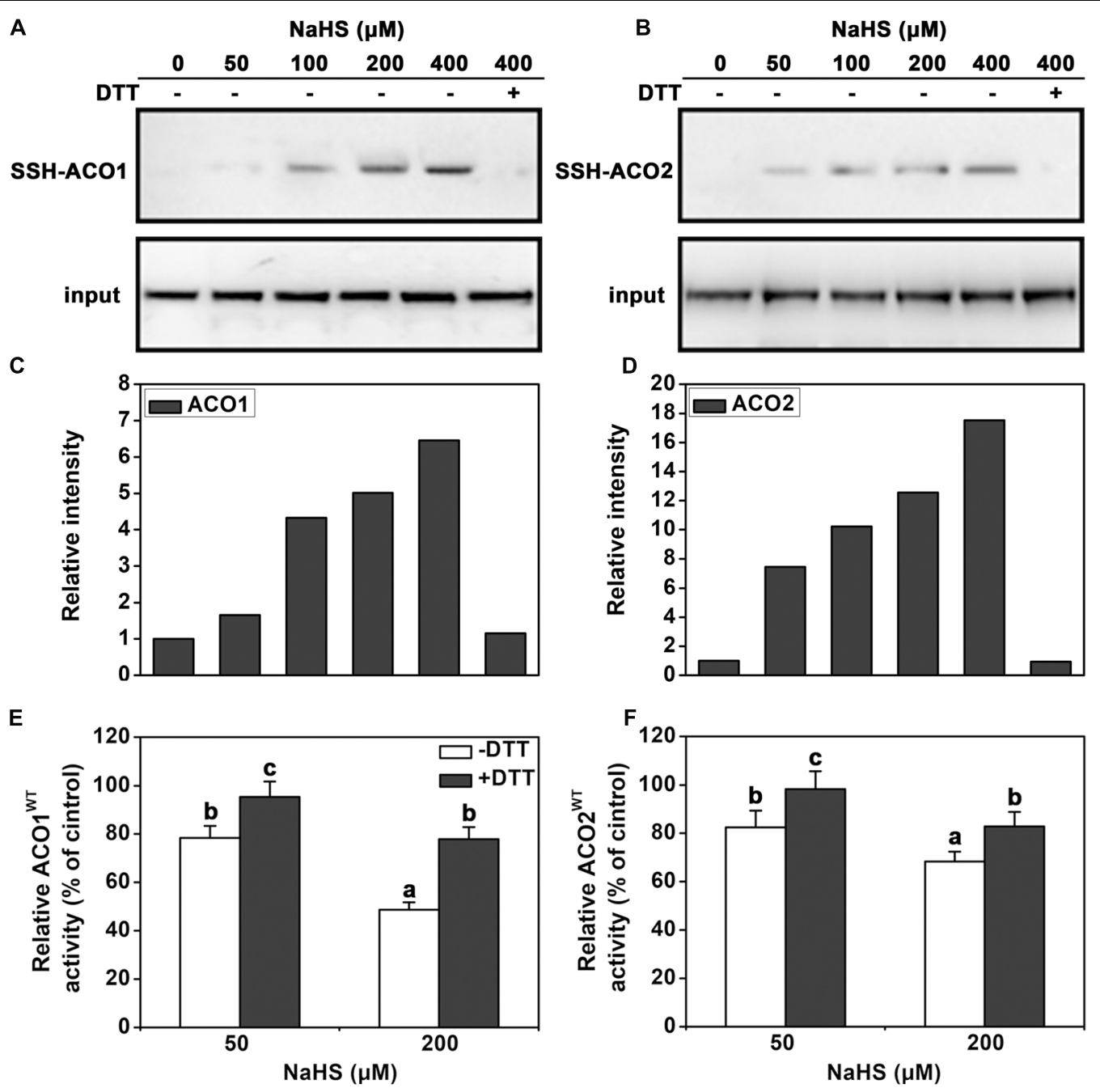

FIGURE 4 | Immunoblot and activity analysis of recombinant LeACO1 and LeACO2 proteins. (A) NaHS-induced persulfidation of LeACO1 was detected using a MBST. (B) Quantification of persulfidation levels that are shown in (A). (C) NaHS-induced persulfidation of LeACO2 was detected using a MBST. (D) Quantification of persulfidation levels that are shown in (C). Input is anti-his signal, which indicate the total protein amount. Persulfidated proteins were labeled with biotin and analyzed using an anti-biotin antibody. Total proteins were analyzed using an anti-his antibody. Effect of NaHS-induced persulfidation on LeACO1 (E) and LeACO2 (F) activity. Recombinant proteins were pretreated with NaHS and NaHS plus DTT (10 mM) for 20 min, and then the immunoblot analysis carried out. Mean values \pm SE are calculated from three replicates. Within each set of experiments, bars with different letters are significant different (Duncan's multiple range tests, $P<0.05$ ).

LeACO1 ${ }^{\mathrm{WT}}$, LeACO1 ${ }^{\mathrm{C} 60 \mathrm{~S}}$ was insensitive to NaHS treatment (Figure 5C). In addition, DTT removed the effect of NaHS (Figure 5C).

\section{$\mathrm{H}_{2} \mathrm{~S}$ Inhibited the Expression of LeACO1 and LeACO2 Genes Under Osmotic Stress}

To investigate in how far $\mathrm{H}_{2} \mathrm{~S}$ influences the transcription of ACC oxidase, the relative expressions of LeACO1 and LeACO2 were analyzed in tomato leaves. Quantitative real-time PCR showed that the gene expressions of LeACO1 and LeACO2 were not changed by NaHS or osmotic stress at $3 \mathrm{~h}$ (Figure 6). However, the gene expressions of LeACO1 and LeACO2 were markedly induced after $24 \mathrm{~h}$ exposure to osmotic stress. Interestingly, this increase was attenuated when NaHS was supplied to the stressed plants (Figure 6). The results suggest that $\mathrm{H}_{2} \mathrm{~S}$ does not directly affects ACC oxidase expression.

\section{DISCUSSION}

\section{$\mathrm{H}_{2} \mathrm{~S}$ Is Required for Ethylene-Induced Stomatal Closure}

The data of García-Mata and Lamattina (2010) has provided evidences that $\mathrm{H}_{2} \mathrm{~S}$ could induce the stomatal closure of Arabidopsis, Vicia faba and Impatiens walleriana. Here, we show that these results also apply to tomato (Figure 1). It is interesting that $\mathrm{H}_{2} \mathrm{~S}$ signal often interacts with phytohormone or signaling molecules to regulate many physiological processes (Hou et al., 


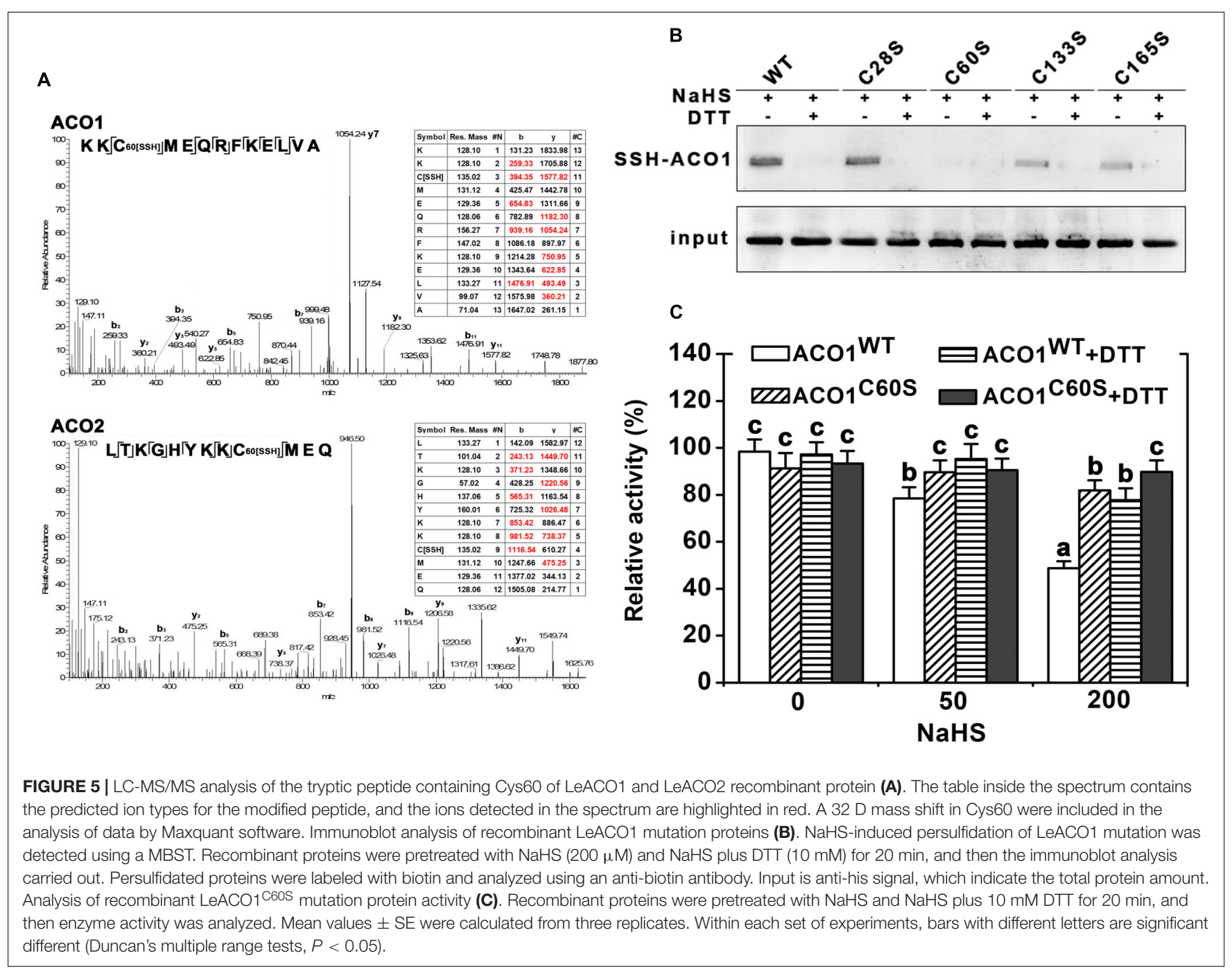

2013; Scuffi et al., 2014; Jia et al., 2015). Recently, $\mathrm{H}_{2} \mathrm{~S}$ has been proven to participate in ABA- or ETH-induced stomatal closure in Arabidopsis. (García-Mata and Lamattina, 2010; Liu et al., 2011). ABA or ethylene can regulate $\mathrm{H}_{2} \mathrm{~S}$ generation. $\mathrm{H}_{2} \mathrm{~S}$ production in tomato is shown to be induced by ethylene similar to what was observed in Arabidopsis and V. faba (Figure 2A; Liu et al., 2011, 2012). Furtherly, our results provided details of how $\mathrm{H}_{2} \mathrm{~S}$ signaling and ethylene signaling act together in the osmotic stress response. Importantly, the stomatal opening in response to osmotic stress is shown to depend on $\mathrm{H}_{2} \mathrm{~S}$ signaling as it could be prevented by application of a scavenger or inhibitor of $\mathrm{H}_{2} \mathrm{~S}$ synthesis. Pharmacological studies also showed that ethylene is insufficient to induce stomatal closure when $\mathrm{H}_{2} \mathrm{~S}$ action is inhibited (Figure 2E). These results strongly suggested that $\mathrm{H}_{2} \mathrm{~S}$ is an important signal molecule involved in ethylene signal, at least in the osmotic stress response of guard cells. Furthermore, results confirmed that $\mathrm{H}_{2} \mathrm{~S}$ signaling generally interacts with phytohormone signaling to regulate the physiological processes (Hou et al., 2013; Scuffi et al., 2014; Jia et al., 2015).

\section{$\mathrm{H}_{2} \mathrm{~S}$ Controls Feedback Regulation of Ethylene Biosynthesis Through Persulfidation of LeACO1 and LeACO2}

1-aminocyclopropane-1-carboxylic acid oxidases regulate the last, rate-limiting step of ethylene biosynthesis (Argueso et al., 2007). The activity of ACOs was shown to directly affect the endogenous ethylene content (Groen and Whiteman, 2014). It was reported that the activity of ACOs is regulated by plant signaling molecules, such as nitric oxide (Tierney et al., 2005; Zhu et al., 2006). Recently, it was suggested that $\mathrm{H}_{2} \mathrm{~S}$ antagonizes the effect of ethylene action in banana fruit ripening and senescence (Ge et al., 2017). Therefore, $\mathrm{H}_{2} \mathrm{~S}$ may resist the function of ETH. In this work, we found that $\mathrm{H}_{2} \mathrm{~S}$ inhibited the ETH generation under osmotic stress (Figure 4). In addition, the activity of ACO also is inhibited by $\mathrm{H}_{2} \mathrm{~S}$ in tomato leave which is similar to nitric oxide (Zhu et al., 2006).

In this work, we found that $\mathrm{H}_{2} \mathrm{~S}$ inhibited the ethylene generation under osmotic stress condition, presumably due to the inhibition of ACO activity (Figure 3). This regulation was shown here to work via persulfidation of one specific cysteine residue 


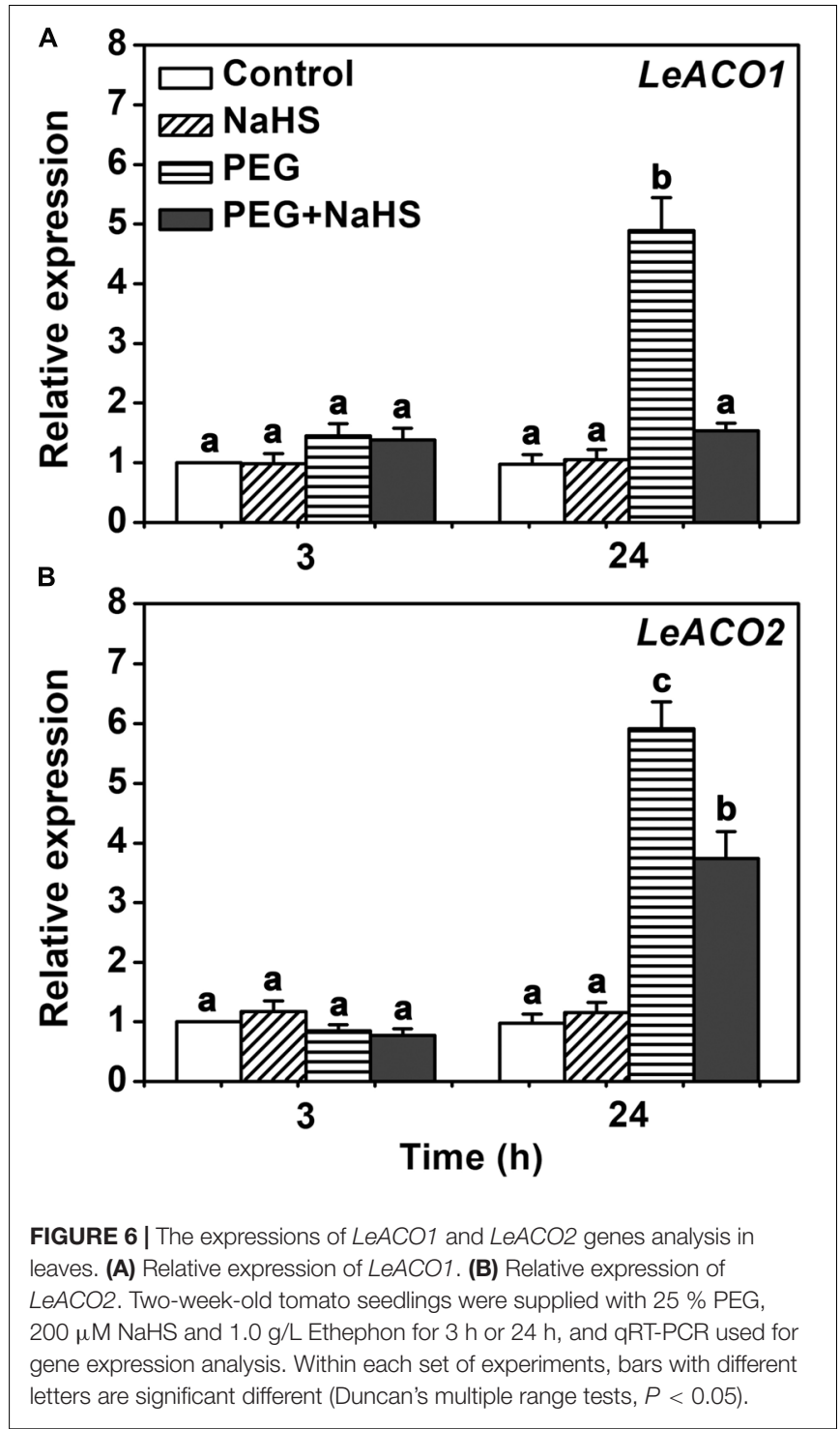

of the LeACO proteins (Figures 4, 5). Negative enzyme activity regulation by $\mathrm{H}_{2} \mathrm{~S}$-induced persulfidation has been previously reported for the protein tyrosine phosphatase PTP1B (Krishnan et al., 2011) and a phosphodiesterase (Bucci and Cirino, 2011). In addition, LeACO ${ }^{\mathrm{C} 60 \mathrm{~S}}$ was insensitive to NaHS treatment comparison with LeACO1 ${ }^{\mathrm{WT}}$, suggesting that the Cys60 is the target site of $\mathrm{H}_{2} \mathrm{~S}$-induced persulfidation.

\section{$\mathrm{H}_{2} \mathrm{~S}$ Inhibits the Transcription of Ethylene Biosynthesis Genes Through an Indirect Way}

Transcriptional regulation of ethylene biosynthesis genes is an important way for modulating ethylene signaling. Phytohormone, signaling molecules and environment stress can change the transcription of these genes, including ethylene itself (Wang et al., 2002). Our data showed that $\mathrm{H}_{2} \mathrm{~S}$ did not alter the expressions of LeACOs within $3 \mathrm{~h}$ (Figure 6), suggesting

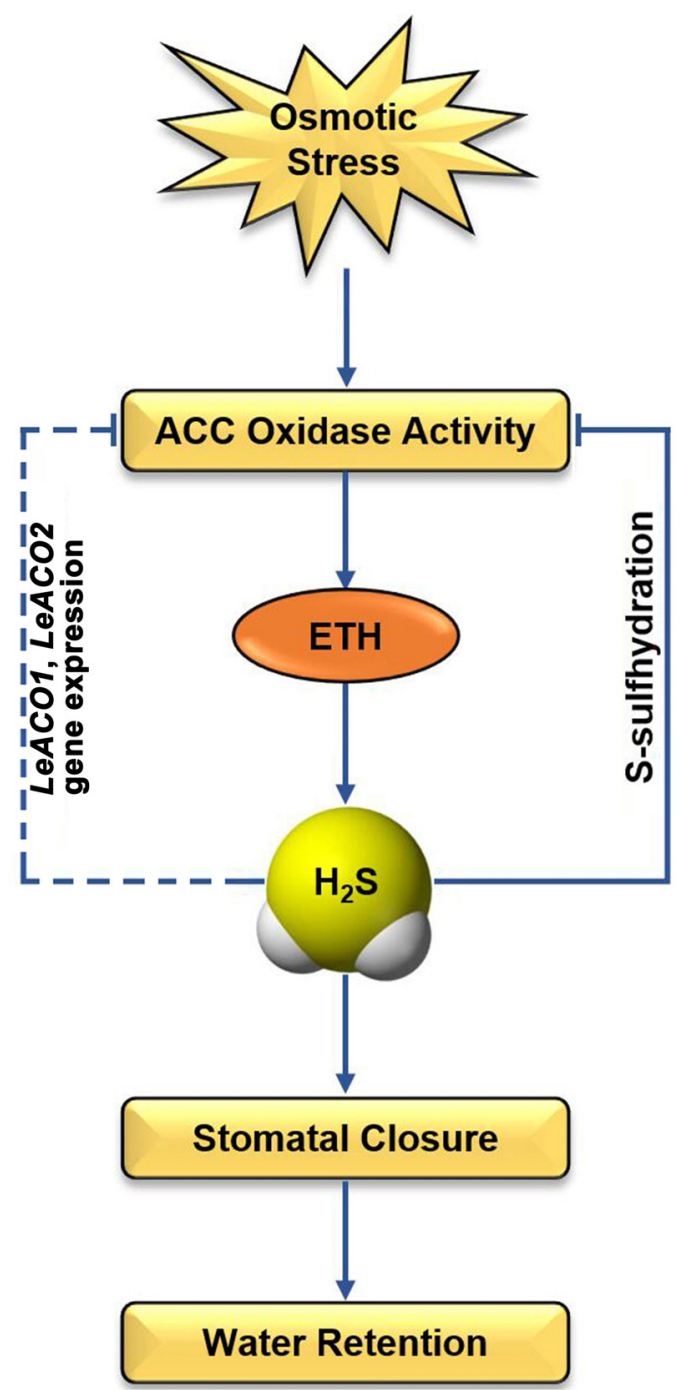

FIGURE 7 | Schematic diagram illustrating the proposed signaling regulation of ethylene-induced $\mathrm{H}_{2} \mathrm{~S}$ negatively regulates ethylene biosynthesis in tomato. Arrows indicate enhanced effects and hyphens indicate suppressed effects.

that $\mathrm{H}_{2} \mathrm{~S}$ did not directly affect the transcriptions of LeACOs. While expression of LeACO1 and LeACO2 under osmotic stress at the late time point $(24 \mathrm{~h})$ was reduced in $\mathrm{H}_{2} \mathrm{~S}$-treated plants compared to control plants, this is likely to be an indirect effect of the $\mathrm{H}_{2} \mathrm{~S}$-induced inhibition of ACO activity. This reduces ethylene content and, thereby, reduce the positive regulation of ethylene biosynthesis by ethylene itself that has been documented previously (Jakubowicz et al., 2010).

\section{CONCLUSION}

$\mathrm{ETH}$, as a stress phytohormone, generates under environmental stress and enhances the resistance of plants (Bleecker and Kende, 2000). However, the excessive accumulation of ETH led to cell senescence and programmed cell death (Lacey and Binder, 2014). 
Therefore, the regulation of ETH biosynthetic is important for plant under environmental stress. Our study revealed a novel mechanism that is $\mathrm{H}_{2} \mathrm{~S}$ feedback regulates ETH biosynthesis in tomato under osmotic stress (Figure 7). Our evidences provided that ETH enhances the accumulation of $\mathrm{H}_{2} \mathrm{~S}$ in guard cells. $\mathrm{H}_{2} \mathrm{~S}$ plays the dual role ethyleneinduced stomatal closure. On the one hand, ETH-induced $\mathrm{H}_{2} \mathrm{~S}$ is a required for ETH-induced stomatal closure. On the other hand, ethylene-induced $\mathrm{H}_{2} \mathrm{~S}$ negatively regulates ethylene biosynthesis through persulfidation of LeACO1 and LeACO2. Post-translational modification of ACOs maybe a direct way of $\mathrm{H}_{2} \mathrm{~S}$ regulates ETH biosynthesis. In addition, $\mathrm{H}_{2} \mathrm{~S}$ also inhibits the transcription of ETH biosynthesis genes through an indirect way. Overall, this study presents compelling evidence supporting interaction between ethylene and $\mathrm{H}_{2} \mathrm{~S}$ and these results are important in context of the biotechnological improvement of osmotic stress tolerant tomato plants.

\section{AUTHOR CONTRIBUTIONS}

JiL and HJ designed and performed the research. SC, JY, CS, XW, and WS screened the mutant plants. HJ, SC, DL, JW, MR, CS, XW

\section{REFERENCES}

Argueso, C. T., Hansen, M., and Kieber, J. J. (2007). Regulation of ethylene biosynthesis. J. Plant Growth Regul. 26, 92-105. doi: 10.1007/s00344-0070013-5

Aroca, Á., Benito, J. M., Gotor, C., Romero, L. C., and Kopriva, S. (2017a). Persulfidation proteome reveals the regulation of protein function by hydrogen sulfide in diverse biological processes in Arabidopsis. J. Exp. Bot. 68, 4915-4927. doi: $10.1093 / \mathrm{jxb} / \mathrm{erx} 294$

Aroca, Á., Schneider, M., Scheibe, R., Gotor, C., and Romero, L. C. (2017b). Hydrogen sulfide regulates the cytosolic/nuclear partitioning of glyceraldehyde3-phosphate dehydrogenase by enhancing its nuclear localization. Plant Cell Physiol. 258, 983-992. doi: 10.1093/pcp/pcx056

Aroca, Á., Serna, A., Gotor, C., and Romero, L. C. (2015). S-sulfhydration: a cysteine posttranslational modification in plant systems. Plant Physiol. 168, 334-342. doi: 10.1104/pp.15.00009

Bleecker, A. B., and Kende, H. (2000). Ethylene: a gaseous signal molecule in plants. Annu. Rev. Cell Dev. Biol. 16, 1-18. doi: 10.1146/annurev.cellbio.16.1.1

Bucci, M., and Cirino, G. (2011). Hydrogen sulphide in heart and systemic circulation. Inflamm. Allergy Drug Targets 10, 103-108. doi: 10.2174/ 187152811794776204

Chao, W. S., Serpe, M., Suttle, J. C., and Jia, Y. (2013). Increase in ACC oxidase levels and activities during paradormancy release of leafy spurge (Euphorbia esula) buds. Planta 238, 205-215. doi: 10.1007/s00425-0131887-z

Chen, J., Shang, Y. T., Wang, W. H., Chen, X. Y., He, E. M., Zheng, H. L., et al. (2016). Hydrogen sulfide-mediated polyamines and sugar changes are involved in hydrogen sulfide-induced drought tolerance in spinacia oleracea seedlings. Front. Plant Sci. 7:1173. doi: 10.3389/fpls.2016.01173

Christou, A., Manganaris, G. A., Papadopoulos, I., and Fotopoulos, V. (2013). Hydrogen sulfide induces systemic tolerance to salinity and non-ionic osmotic stress in strawberry plants through modification of reactive species biosynthesis and transcriptional regulation of multiple defence pathways. J. Exp. Bot. 647, 1953-1966. doi: 10.1093/jxb/ert055

Fang, H., Liu, Z., Jin, Z., Zhang, L., Liu, D., and Pei, Y. (2016). An emphasis of hydrogen sulfide-cysteine cycle on enhancing the tolerance to chromium stress in Arabidopsis. Environ. Pollut. 213, 870-877. doi: 10.1016/j.envpol.2016. 03.035 and JY analyzed the data. JoL edited the language. JiL wrote the paper.

\section{FUNDING}

This work was supported by the Natural Science Foundation of China (NSFC Nos. 31700445 and 31400246), the Shaanxi Natural Science Foundation of China (2018JM3017 and 2018JQ3020), and Northwest A\&F University basic research Foundation (No. 2452018156).

\section{ACKNOWLEDGMENTS}

Thanks for Northwest A\&F University Life Science Research Core Services.

\section{SUPPLEMENTARY MATERIAL}

The Supplementary Material for this article can be found online at: https://www.frontiersin.org/articles/10.3389/fpls.2018.01517/ full\#supplementary-material

Gao, S. P., Hu, K. D., Hu, L. Y., Li, Y. H., Han, Y., and Wang, H. L. (2013). Hydrogen sulfide delays postharvest senescence and plays an antioxidative role in fresh-cut kiwifruit. HortScience 48, 1385-1392.

García-Mata, C., and Lamattina, L. (2010). Hydrogen sulphide, a novel gasotransmitter involved in guard cell signalling. New Phytol. 188, 977-984. doi: 10.1111/j.1469-8137.2010.03465.x

Ge, Y., Hu, K. D., Wang, S. S., Hu, L. Y., Chen, X. Y., Li, Y. H., et al. (2017) Hydrogen sulfide alleviates postharvest ripening and senescence of banana by antagonizing the effect of ethylene. PLoS One 29:e0180113. doi: 10.1371/journal. pone. 0180113

Groen, S. C., and Whiteman, N. K. (2014). The evolution of ethylene signaling in plant chemical ecology. J. Chem. Ecol. 40, 700-716. doi: 10.1007/s10886-0140474-5

Guo, H., Zhou, H., Zhang, J., Guan, W., Xu, S., Shen, W., et al. (2017). L-cysteine desulfhydrase-related $\mathrm{H} 2 \mathrm{~S}$ production is involved in OsSE5promoted ammonium tolerance in roots of Oryza sativa. Plant Cell Environ. 2017, 1777-1790. doi: 10.1111/pce.12982

Hou, Z., Wang, L., Liu, J., Hou, L., and Liu, X. (2013). Hydrogen sulfide regulates ethylene-induced stomatal closure in Arabidopsis thaliana. J. Integr. Plant Biol. 55, 277-289. doi: 10.1111/jipb.12004

Jakubowicz, M., Gałgańska, H., Nowak, W., and Sadowski, J. (2010). Exogenously induced expression of ethylene biosynthesis, ethylene perception, phospholipase D, and R boh-oxidase genes in broccoli seedlings. J. Exp. Bot. 61, 3475-3491. doi: 10.1093/jxb/erq177

Jia, H., Hu, Y., Fan, T., and Li, J. (2015). Hydrogen sulfide modulates actindependent auxin transport via regulating ABPs results in changing of root development in Arabidopsis. Sci. Rep. 5:8251. doi: 10.1038/srep08251

Jia, H., Wang, X., Dou, Y., Liu, D., Si, W., Fang, H., et al. (2016). Hydrogen sulfide-cysteine cycle system enhances cadmium tolerance through alleviating cadmium-induced oxidative stress and ion toxicity in Arabidopsis roots. Sci. Rep. 6:39702. doi: 10.1038/srep39702

Kende, H. (1993). Ethylene biosynthesis. Annu. Rev. Plant Physiol. Plant Mol. Biol. 44, 283-307. doi: 10.1146/annurev.pp.44.060193.001435

Kopriva, S. (2006). Regulation of sulfate assimilation in Arabidopsis and beyond. Ann. Bot. 97, 479-495. doi: 10.1093/aob/mcl006

Krishnan, N., Fu, C., Pappin, D. J., and Tonks, N. K. (2011). H2S-induced sulfhydration of the phosphatase PTP1B and its role in the endoplasmic reticulum stress response. Sci. Signal. 4:ra86. doi: 10.1126/scisignal.2002329 
Lacey, R. F., and Binder, B. M. (2014). How plants sense ethylene gas-the ethylene receptors. J. Inorg. Biochem. 133, 58-62. doi: 10.1016/j.jinorgbio.2014.01.006

Li, J., Jia, H., Wang, J., Cao, Q., and Wen, Z. (2014). Hydrogen sulfide is involved in maintaining ion homeostasis via regulating plasma membrane $\mathrm{Na}+/ \mathrm{H}+$ antiporter system in the hydrogen peroxide-dependent manner in salt-stress Arabidopsis thaliana root. Protoplasma 251, 899-912. doi: 10.1007/s00709-0130592-x

Liu, J., Hou, L., Liu, G., Liu, X., and Wang, X. (2011). Hydrogen sulfide induced by nitric oxide mediates ethylene-induced stomatal closure of Arabidopsis thaliana. Chin. Sci. Bull. 56, 3547-3553. doi: 10.1007/s11434-011-4819-y

Liu, J., Hou, Z., Liu, G., Hou, L., and Liu, X. (2012). Hydrogen sulfide may function downstream of nitric oxide in ethylene-induced stomatal closure in vicia faba. J. Integr. Agric. 11, 1644-1653. doi: 10.1016/S2095-3119(12)60167-1

Madhaiyan, M., Poonguzhali, S., and Sa, T. M. (2007). Characterization of 1-aminocyclopropane-1-carboxylate (ACC) deaminase containing Methylobacterium oryzae and interactions with auxins and ACC regulation of ethylene in canola (Brassica campestris). Planta 226, 867-876. doi: 10.1007/s00425-007-0532-0

Mustafa, A. K., Gadalla, M. M., Sen, N., Kim, S., Mu, W., Gazi, S. K., et al. (2009). H2S signals through protein S-sulfhydration. Sci. Signal. 2:72. doi: 10.1126/ scisignal.2000464

Papenbrock, J., Riemenschneider, A., Kamp, A., Schulz-Vogt, H. N., and Schmidt, A. (2007). Characterization of cysteine-degrading and H2S-releasing enzymes of higher plants - from the field to the test tube and back. Plant Biol. 9, 582-588. doi: 10.1055/s-2007-965424

Satoh, S., and Kosugi, Y. (2017). Escherichia coli-Based expression and in vitro activity assay of 1-aminocyclopropane-1-carboxylate (ACC) synthase and ACC oxidase. Methods Mol. Biol. 1573, 47-58. doi: 10.1007/978-1-49396854-1_5

Scuffi, D., Álvarez, C., Laspina, N., Gotor, C., Lamattina, L., and García-Mata, C. (2014). Hydrogen sulfide generated by l-cysteine desulfhydrase acts upstream of nitric oxide to modulate abscisic acid-dependent stomatal closure. Plant Physiol. 166, 2065-2076. doi: 10.1104/pp.114.245373
Spanu, P., Reinhardt, D., and Boller, T. (1991). Analysis and cloning of the ethylene-forming enzyme from tomato by functional expression of its mRNA in Xenopus laevis oocytes. EMBO J. 10, 2007-2013. doi: 10.1002/j.1460-2075. 1991.tb07730.x

Tan, B. H., Wong, P. T. H., and Bian, J. S. (2010). Hydrogen sulfide: a novel signaling molecule in the central nervous system. Neurochem. Int. 56, 3-10. doi: 10.1016/j.neuint.2009.08.008

Tierney, D. L., Rocklin, A. M., Lipscomb, J. D., Que, L. Jr., and Hoffman, B. M. (2005). ENDOR studies of the ligation and structure of the non-heme iron site in ACC oxidase. J. Am. Chem. Soc. 18, 7005-7013. doi: 10.1021/ja050 0862

Wang, K. L., Li, H., and Ecker, J. R. (2002). Ethylene biosynthesis and signaling networks. Plant Cell 14, S131-S151. doi: 10.1105/tpc.001768

Xie, Y., Zhang, C., Lai, D., Sun, Y., Samma, M. K., Zhang, J., et al. (2014). Hydrogen sulfide delays GA-triggered programmed cell death in wheat aleurone layers by the modulation of glutathione homeostasis and heme oxygenase-1 expression. J. Plant Physiol. 171, 53-62. doi: 10.1016/j.jplph.2013.09.018

Zhu, S. H., Liu, M. C., and Zhou, J. (2006). Inhibition by nitric oxide of ethylene biosynthesis and lipoxygenase activity in peach fruit during storage. Postharvest Biol. Technol. 41, 41-48. doi: 10.1016/j.postharvbio.2006. 05.004

Conflict of Interest Statement: The authors declare that the research was conducted in the absence of any commercial or financial relationships that could be construed as a potential conflict of interest.

Copyright (c) 2018 Jia, Chen, Liu, Liesche, Shi, Wang, Ren, Wang, Yang, Shi and Li. This is an open-access article distributed under the terms of the Creative Commons Attribution License (CC BY). The use, distribution or reproduction in other forums is permitted, provided the original author(s) and the copyright owner(s) are credited and that the original publication in this journal is cited, in accordance with accepted academic practice. No use, distribution or reproduction is permitted which does not comply with these terms. 